UDK: 528.4(497.11)

DOI: https://doi.org/10.24867/08KG03Jevtic

\title{
АУТОМАТИЗАЦИЈА ПРОЦЕСА ИНИЦИРАҢА КОМАСАЦИОНИХ ПРОЈЕКАТА У ОПШТИНИ ВРБАС
}

\section{AUTOMATIZATION OF THE PROCESS OF INITIATION OF LAND CONSOLIDATION PROJECTS IN THE MUNICIPALITY OF VRBAS}

\author{
Наташа Јевтић, Горан Маринковић, Факултет техничких наука, Нови Сад
}

\section{Област - ГЕОДЕЗИЈА И ГЕОМАТИКА}

Кратак садржај - У овом раду извриено је рангирање катастарских општина у општини Врбас употребом TOPSIS, ELECTRE, SAW u AHP метода, које cy имплементиране у програм користећи програмски језик MATLAB.

Кључне ријечи: Комасација, вишекритеријумска оптимизација, TOPSIS, ELECTRE, SAW, AHP

Abstract - This thesis present the ranking of cadastral municipalities in Vrbas using TOPSIS, ELECTRE, SAW and AHP methods, which are implemented in the program by using the programming language MATLAB.

Keywords: Land consolidation, Multi-criteria optimization, TOPSIS, ELECTRE, SAW, AHP

\section{1. УВОД}

Комасација представља систем који обухвата планске, организационе, правне, економске и техничке мјере које се спроводе у циљу укрупњавања и побољшавања природних и еколошких услова на земљишту [1]. Пројекти из области комасације су веома захтјевни и за себе везују велика финансијска улагања. Комасационе пројекте би требало реализовати у више катастарских општина, али због недостатка новчаних средстава за реализацију свих пројеката, то није могуће. Тада је потребно донијети одлуку који комасациони пројекти би на најбољи начин достигли постављене циљеве. Да би се извршио избор између катастарских општина у којима he ce спровести уређење пољопривредног земљишта путем комасације, потребно их је рангирати према одређеним критеријумима.

Развијен је велики број метода и техника које су нашле примјену у процесу доношења одлука, при чему се најчешће користе методе вишекритеријумског одлучивања. Њих карактерише доношење одлука у случајевима постојања више дефинисаних критеријума коју су често конфликтни.

Избор катастарских општина у којима ће се реализовати комасациони пројекат неопходно је извршити употребом објективних математичких модела оптимизације. Примјеном метода вишекритеријумске

\section{НАПОМЕНА:}

Овај рад проистекао је из мастер рада чији ментор је био др Горан Маринковић, доцент. анализе обезбјеђује се објективан начин избора.

Вишекритеријумска анализа представља низ техника помоћу којих се врши рангирање алтернатива, од најпожељније према најмање преферираној. Подаци и информације о алтернативама сажимају се одговарајућим поступцима у по један број за сваку алтернативу, те се на основу тих вриједности одређује ранг листа алтернатива [2].

Предмет истраживања у овом раду је рангирање катастарских општина за уређење пољопривредног земљишта комасацијом и могућност примјене програмском језика $M A T L A B$, у овој области.

Циљ истраживања је да се примјеном MATLAB-a креира софтверски пакет, којим ће се извршити рангирање катастарских општина у Општини Врбас.

\section{2. МАТЕРИЈАЛ И МЕТОДЕ}

Материјал за ову студију је обухватио седам од осам катастарских општина које припадају општини Врбас. За потребе ове анализе изузета је КО Врбас-град, јер она представља грађевински реон. Подаци су прикупљени од низа релевантних државних установа. Због велике количине података, њихово презентовање је овдје изостављено.

У циљу рангирања општина за покретање комасационих пројеката у општини Врбас, дефинисани су и предложени следећи критеријуми за рангирање:

Ф1: Удио обрадивог земљишта у укупном пољопривредном земљишту,

Ф2: Удио државне својине у укупној површини,

Ф3: Површина државног земљишта која се даје у закуп,

Ф4: Просјечна површина парцеле у ванграђевинском реону,

Ф5: Број парцела по листу непокретности,

Ф6: Просјечна величина посједа у ванграђевинском реону,

Ф7: Број посједника са површином већом од 5 ха,

Ф8: Стање премјера,

Ф9: Стање комасације.

С обзиром да критеријуми нису исте важности и да немају исти утицај на посматране алтернативе, потребно им је додјелити тежине према њиховим важностима. У овом раду, тежинске вриједности критеријума су израчунате на основу АНP методе. За сваки критеријум је дефинисан и циљ, односно које критеријуме треба максимизирати, а које минимизирати. 
Имплементацијом TOPSIS, ELECTRE, SAW и AHP метода у програм који је развијен у оквиру MATLAB App Designer-a, извршиће се рангирање седам катастарских општина и самим тим одредити којој катастарској општини треба дати приоритет за покретање и реализацију комасационог пројекта. Математички модели примјењених вишекритеријумских метода презентовани су у многим радовима $[3,4,5,6,7,8]$, па је њихов детаљан опис овдје изостављен.

\section{1. Развој програма за рангирање катастарских општина}

За развој овог програма одабрано је MATLAB програмско окружење, јер омогућава ефикасан рад са матрицама и векторима. Имплементација алгоритама метода вишекритеријумског одлучивања извршена је преко MATLAB-ових функција. Апликација за процесирање података развијена је у оквиру MATLAB App Designer-a, који интегрише два основна задатка креирања апликација - графички кориснички интерфејс и програмирање понашања апликације. Преко апликације се позивају $m$-функције којима су имплементиране методе TOPSIS, ELECTRE, SAW и AHP. Главни прозор програма се састоји из три панела (Слика 1):

- панел за унос улазних података,

- панел за рачунање ранга алтернатива и

- панел за графички приказ резултата.

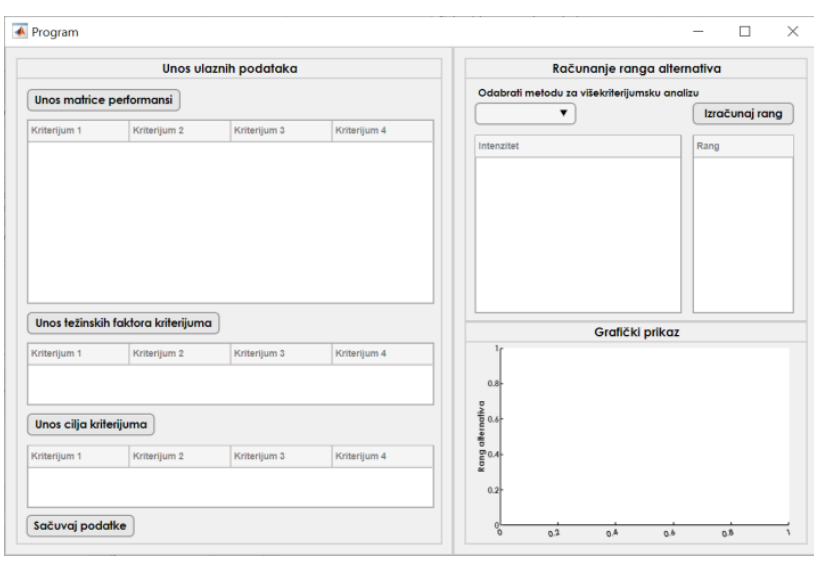

Слика 1. Главни прозор програма

Улазни подаци су матрица перформанси, која се формира на основу прикупљених података о катастарским општинама, тежине критеријума и њихови циљеви. Панел за унос улазних података омогућава да се преко Microsoft Excel документа учитају подаци у софтвер, који морају испоштовати одговарајућу форму, приказану на сликама 2, 3, и 4.

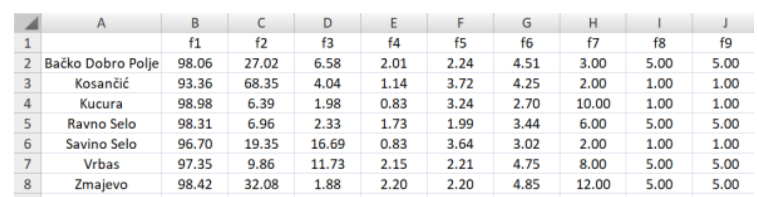

Слика 2. Форма за унос матрице перформанси

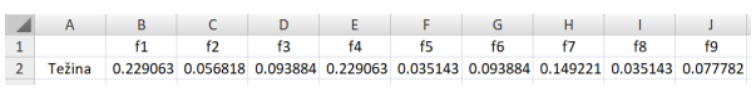

Слика 3. Форма за унос тежина критеријума

\begin{tabular}{|l|c|c|c|c|c|c|c|c|c|c|}
\hline $\mathbf{4}$ & $\mathrm{A}$ & $\mathrm{B}$ & $\mathrm{C}$ & $\mathrm{D}$ & $\mathrm{E}$ & $\mathrm{F}$ & $\mathrm{G}$ & $\mathrm{H}$ & $\mathrm{I}$ & $\mathrm{J}$ \\
\hline 1 & & $\mathrm{f} 1$ & $\mathrm{f} 2$ & $\mathrm{f3}$ & $\mathrm{f} 4$ & $\mathrm{f5}$ & $\mathrm{f} 6$ & $\mathrm{f7}$ & $\mathrm{f} 8$ & $\mathrm{f} 9$ \\
\hline 2 & Cilj & $\max$ & $\max$ & $\max$ & $\min$ & $\max$ & $\max$ & $\max$ & $\min$ & $\min$ \\
\hline
\end{tabular}

Слика 4. Форма за унос ичљља критеријума

Након што су улазни подаци учитани у програм (Слика 5), потребно их је сачувати у workspace $M A T L A B$-а како би се $m$-функције метода могле извршити. Овим софтвером је омогућено да се учитају улазни подаци преко Microsoft Excel документа, да се избором једне од четири понуђених метода израчунају интензитет и ранг алтернатива, а затим да се ти резултати прикажу нумерички и графички.

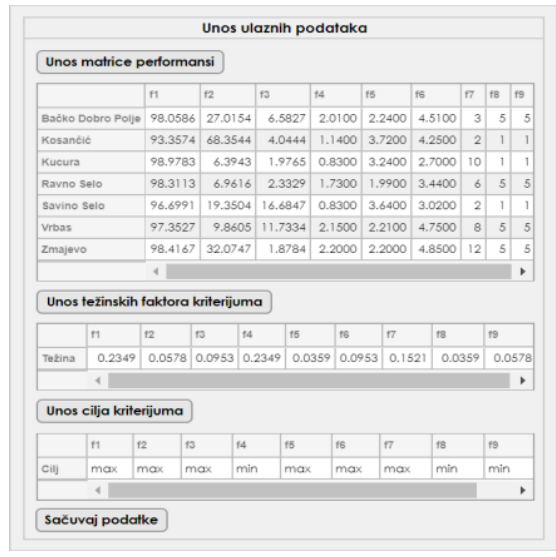

Слика 5. Приказ учитаних података у програм

Софтвер садржи системе за провјеру и обавјештава корисника о врсти грешке у случају да:

- није унесена матрица перформанси, циљеви или тежине критеријума,

- се покуша одабрати метода за вишекритеријумску анализу, а улазни подаци нису сачувани,

- ce покуша израчунати ранг алтернатива, а улазни подаци нису сачувани,

- ce без претходно одабране методе за вишекритеријумску оптимизацију покуша израчунати ранг алтернатива.

\section{3. РЕЗУЛТАТИ}

Као резултат примјене развијеног софтвера, добијају се интензитети и рангови катастарских општина у општини Врбас. Њихов нумерички приказ је дат на сликама $6,8,10$ и 12, а графички на сликама 7, 9, 11 и 13.

\begin{tabular}{|c|c|c|}
\hline \multicolumn{3}{|c|}{ Računanje ranga alternativa } \\
\hline \multicolumn{3}{|c|}{ Odabrati metodu za višekriterijumsku analizu } \\
\hline TOPSIS & 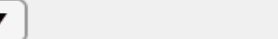 & Izračunaj rang \\
\hline & Funkcija Dp & Rang \\
\hline Bačko Dobro Polje & 0.2247 & 7 \\
\hline Kosančić & 0.4428 & 4 \\
\hline Kucura & 0.5573 & 1 \\
\hline Ravno Selo & 0.2820 & 6 \\
\hline Savino Selo & 0.5349 & 2 \\
\hline Vrbas & 0.4150 & 5 \\
\hline Zmajevo & 0.4472 & 3 \\
\hline
\end{tabular}

Слика 6. Приказ резултата добијених примјеном TOPSIS методе 


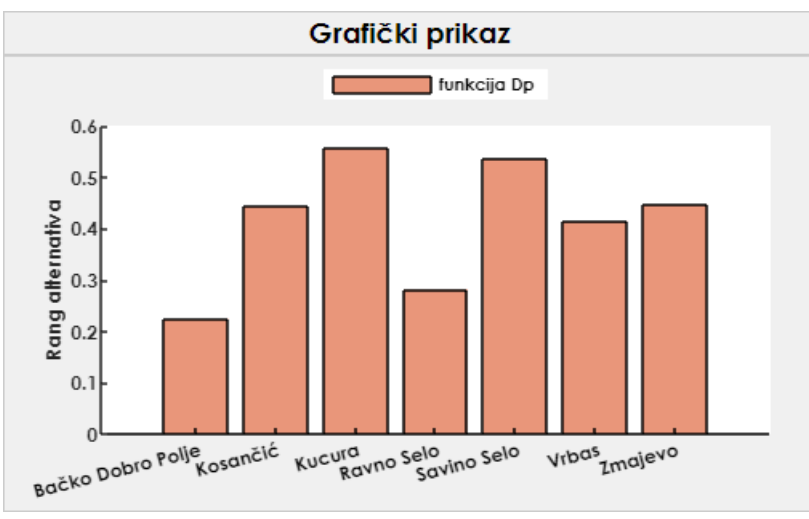

Слика 7. Графички приказ резултата добијених примјеном TOPSIS методе

\begin{tabular}{|c|c|c|c|c|}
\hline \multicolumn{5}{|c|}{ Računanje ranga alternativa } \\
\hline \multicolumn{5}{|c|}{ Odabrati metodu za višekriterijumsku analizu } \\
\hline \multirow[t]{2}{*}{ ELECTRE } & $\nabla$ & & & Izračunaj rang \\
\hline & nost C & Nesag... & & Rang \\
\hline Bačko Dobro Polje & -0.5581 & 3.8995 & $\Delta$ & 4 \\
\hline Kosančić & -0.7637 & -0.1237 & & 5 \\
\hline Kucura & 2.3388 & -3.0327 & & 1 \\
\hline Ravno Selo & -0.6390 & 2.2726 & & 6 \\
\hline Savino Selo & 0.1830 & -1.8798 & & 2 \\
\hline Vrbas & -0.8107 & -0.5541 & & 7 \\
\hline \multirow[t]{2}{*}{ Zmajevo } & 0.2497 & -0.5818 & $\nabla$ & 3 \\
\hline & 4 & 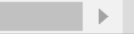 & & \\
\hline
\end{tabular}

Слика 8. Приказ резултата добијених примјеном ELECTRE методе

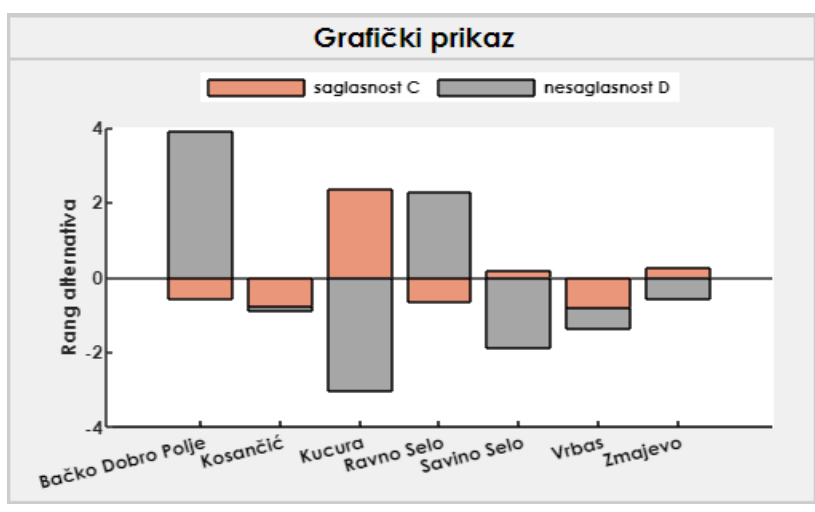

Слика 9. Графички приказ резултата добијених примјеном ELECTRE методе

\begin{tabular}{|c|c|c|}
\hline \multicolumn{3}{|c|}{ Računanje ranga alternativa } \\
\hline \multicolumn{3}{|c|}{ Odabrati metodu za višekriterijumsku analizu } \\
\hline SAW & $\nabla$ & Izračunaj rang \\
\hline & Indeks performansi s & Rang \\
\hline Bačko Dobro Polje & 0.5572 & 6 \\
\hline Kosančić & 0.7120 & 3 \\
\hline Kucura & 0.7913 & 1 \\
\hline Ravno Selo & 0.5469 & 7 \\
\hline Savino Selo & 0.7896 & 2 \\
\hline Vrbas & 0.6320 & 5 \\
\hline Zmajevo & 0.6475 & 4 \\
\hline
\end{tabular}

Слика 10. Приказ резултата добијених примјеном SAW методе

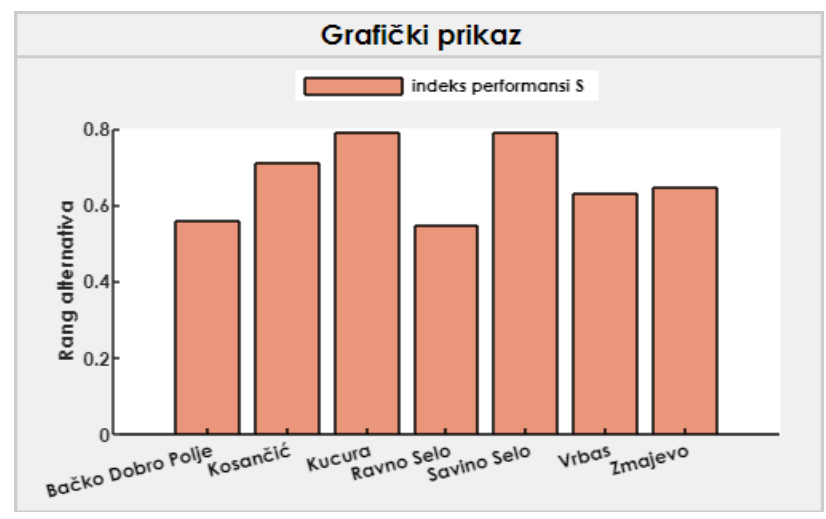

Слика 11. Графички приказ резултата добијених примјеном SAW методе

\begin{tabular}{|c|c|c|}
\hline \multicolumn{3}{|c|}{ Računanje ranga alternativa } \\
\hline \multicolumn{3}{|c|}{ Odabrati metodu za višekriterijumsku analizu } \\
\hline AHP & & Izračunaj rang \\
\hline & Težinski udio & Rang \\
\hline Bačko Dobro Polje & 0.1030 & 7 \\
\hline Kosančić & 0.1465 & 3 \\
\hline Kucura & 0.1928 & 1 \\
\hline Ravno Selo & 0.1083 & 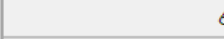 \\
\hline Savino Selo & 0.1818 & 2 \\
\hline Vrbas & 0.1291 & $s$ \\
\hline Zmajevo & 0.1385 & 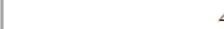 \\
\hline
\end{tabular}

Слика 12. Приказ резултата добијених примјеном AHP методе

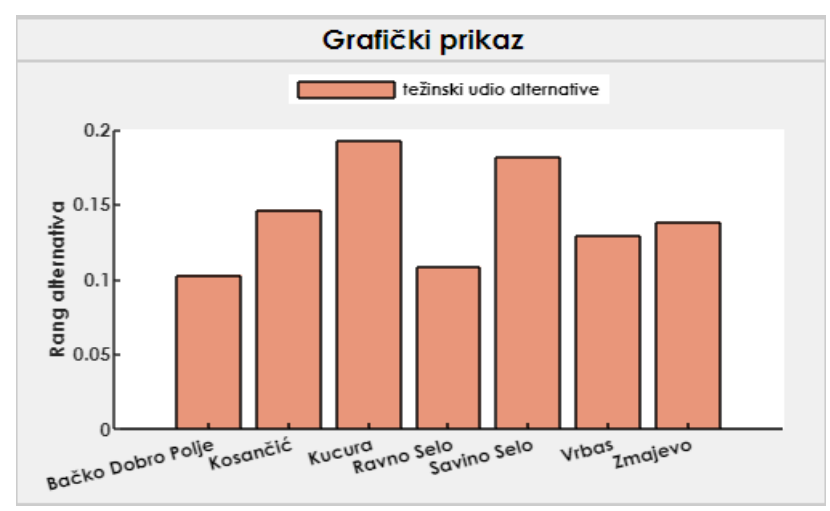

Слика 13. Графички приказ резултата добијених примјеном АНР методе

На основу добијених резултата рангирања извршена је упоредна анализа (Табела 1), којом су добијене разлике у рангу катастарских општина (Табела 2).

Табела 1. Приказ добијених рангова катастарских општина

\begin{tabular}{|c|c|c|c|c|}
\hline Алтернатива & TOPSIS & ELECTRE & SAW & $A H P$ \\
\hline Б. Добро Поље & 7 & 4 & 6 & 7 \\
\hline Косанчић & 4 & 5 & 3 & 3 \\
\hline Куцура & 1 & 1 & 1 & 1 \\
\hline Равно Село & 6 & 6 & 7 & 6 \\
\hline Савино Село & 2 & 2 & 2 & 2 \\
\hline Врбас & 5 & 7 & 5 & 5 \\
\hline Змајево & 3 & 3 & 4 & 4 \\
\hline
\end{tabular}


Табела 2. Разлике у рангу катастарских општина

\begin{tabular}{|c|c|c|c|c|c|c|}
\hline \multirow{2}{*}{ Алтернатива } & $T$ & $T$ & $T$ & $E$ & $E$ & $S$ \\
& - & - & - & - & - & - \\
& $E$ & $S$ & $A$ & $S$ & $A$ & $A$ \\
\hline Бачко Добро Поље & 3 & 1 & - & 2 & 3 & 1 \\
\hline Косанчић & 1 & 1 & 1 & 2 & 2 & - \\
\hline Куцура & - & - & - & - & - & - \\
\hline Равно Село & - & 1 & - & 1 & - & 1 \\
\hline Савино Село & - & - & - & - & - & - \\
\hline Врбас & 2 & - & - & 2 & 2 & - \\
\hline Змајево & - & 1 & 1 & 1 & 1 & - \\
\hline
\end{tabular}

Коначна листа рангирања катастарских општина у општини Врбас добијена је комбинацијом резултата свих примјењених метода (Табела 3 ).

\begin{tabular}{|c|c|}
\hline Ранг & Алтернатива \\
\hline 1 & Куцура \\
\hline 2 & Савино Село \\
\hline 3 & Змајево \\
\hline 4 & Косанчић \\
\hline 5 & Врбас \\
\hline 6 & Бачко Добро Поље \\
\hline 7 & Равно Село \\
\hline
\end{tabular}

\section{4. ДИСКУСИЈА И ЗАКЉУЧНА РАЗМАТРАҢА}

Методе вишекритеријумске анализе имају широку примјену у различитим сферама живота, науке и струке. Постоји велики број развијених метода вишекритеријумске анализе, а свака од њих има за циљ да доносиоцу одлуке помогне при рјешавању комплексних проблема. Један од таквих проблема је избор катастарских општина којима треба дати приоритет за уређење пољопривредног земљишта комасацијом. Веома је важно да се избор изврши коректно и објективно, што примјена метода вишекритеријумске анализе и омогућава.

Циљ овог рада био је рангирати катастарске општине за уређење пољопривредног земљишта комасацијом у Општини Врбас, употребом TOPSIS, ELECTRE, SAW и $A H P$ метода вишекритеријумске анализе и софтвера развијеног у MATLAB-у. У ту сврху предложено је и дефинисано девет критеријума на основу којих је извршено рангирање седам катастарских општина за уређење пољопривредног земљишта комасацијом. Уз сваки критеријум дефинисан је и циљ коме тај критеријум тежи. Додјељивање тежина критеријума извршено је примјеном АНР методе.

Примјеном математичког модела TOPSIS, ELECTRE, $S A W$ и $A H P$ метода, у софтверу је извршено рангирање катастарских општина општине Врбас. Упоредном анализом добијених резултата долази се до закључка да су резултати рангирања катастарских општина веома слични за методе TOPSIS и AHP, као и за $S A W$ и $A H P$. Све методе су исто рангирале катастарске општине Куцура и Савино Село и оне заузимају прве двије позиције. Код осталих катастарских општина постоји разлика у једној или двије позиције. Поређењем ELECTRE методе са методама TOPSIS и AHP, уочена је највећа разлика у рангу, која износи три позиције и односи се на катастарску општину Бачко Добро Поље.
Комбинацијом резултата рангирања примјењених метода вишекритеријумске анализе добијена је коначна ранг листа (Табела 3), према којој приоритет за покретање поступка комасације има катастарска општина Куцура, док је најлошије рангирана катастарска општина Равно Село.

Комбинација ових метода је корисна, јер може пружити помоћ доносиоцима одлуке да на објективан начин изаберу катастарске општине којима ће дати приоритет за уређење пољопривредног земљишта комасацијом.

\section{5. ЛИТЕРАТУРА}

[1] Миладиновић, М.: Уређење земљишне територије, Научна књига, Београд, 1997.

[2] Хот, И.: Управљање израдом генералних пројеката у области инфраструктуре применом вишекритеријумске анализе, докторска дисертација, Универзитет у Новом Саду, Факултет техничких наука, Нови Сад, 2014.

[3] Маринковић, Г.: Прилог развоју методологије оптимизације радова и тачности у пројектима комасације, докторска дисертација, Универзитет у Новом Саду, Факултет техничких наука, Нови Сад, 2015.

[4] Срђевић, Б.: Дискретни модели одлучивања у оптимизацији коришћења каналске мреже у Војводини, Летопис научних радова, Пољопривредни факултет, Нови Сад, 2005.

[5] Marinković, G.; Lazić, J.; Morača, S.; Grgić, I. Integrated assessment methodology for land consolidation projects: Case study Pecinci, Serbia. Arch. Tech. Sci. 2019, 20, 43-52. [CrossRef]

[6] Demetriou, D.; See, L.; Stillwell, J. A Spatial MultiCriteria Model for the Evaluation of Land Redistribution Plans. ISPRS Int. J. Geo-Inf. 2012, 1, 272-293. [CrossRef]

[7] Tomić, H.; Mastelić Ivić, S.; Roić, M. Land Consolidation Suitability Ranking of Cadastral Municipalities: Information-Based Decision-Making Using Multi-Criteria Analyses of Official Registers' Data, ISPRS Int. J. Geo-Inf. 2018, 7(3), 87. [CrossRef]

[8] Lazić, J., Ninkov, T., Trifković, M., Marinković, G., Kuburić, M. Use of TOPSIS Method for ranking cadastral municipalities in the process of land consolidation. J. Fac. Civil Eng. Subotica 2017, 32, 21-44. [CrossRef]

Кратка биографија:

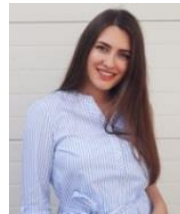

Наташа Јевтић рођена је у Бијељини 1995. године. Мастер рад из области Геодезија и геоматика на Факултету техничких наука у Новом Саду, одбра-нила 2019. године. контакт: nataly.jevtic.95@gmail.com

Горан Маринковић рођен је у Власеници 1968. године. Докторирао је на Факултету техничких наука у Новом Саду 2015. године, а од 2016. је у звању доцента.

контакт: goranmarinkovic@uns.ac.rs 